\title{
Fibroblast Growth Factor Receptor 3
}

National Cancer Institute

\section{Source}

National Cancer Institute. Fibroblast Growth Factor Receptor 3. NCI Thesaurus. Code C26129.

Fibroblast growth factor receptor 3 ( $806 \mathrm{aa}, \sim 88 \mathrm{kDa}$ ) is encoded by the human FGFR3 gene. This protein is involved in fibroblast growth factor signaling and skeletal development. 